\title{
ANALISIS KESALAHAN MORFOLOGI DALAM KARANGAN SEDERHANA BAHASA JERMAN SISWA KELAS XI SMAN 2 MAKASSAR
}

\author{
Agung Rinady Malik ${ }^{1}$ dan Syarifah Fatimah ${ }^{2}$ \\ Fakultas Bahasa dan Sastra, Universitas Negeri Makassar \\ Email1 : agungrinaldy11@yahoo.co.id
}

\begin{abstract}
ABSTRAK
Penelitian ini bertujuan untuk mendapatkan data dan informasi tentang kesalahan siswa kelas XI SMAN 2 Makassar pada tataran morfologi. Jenis penelitan ini adalah deskriptif kualitatif. Pengambilan data dilakukan dengan tes menulis bahasa Jerman. Metode analisis yang digunakan adalah metode agih. Populasi penelitian ini adalah siswa kelas XI SMAN 2 Makassar yang terdiri atas 10 kelas. Sampel penelitian ini adalah Random sampling. Jumlah sampel adalah 1 kelas, yakni; kelas XI IPA 2 yang terdiri atas 24 siswa. Hasil analisis data menunjukkan bahwa kesalahan morfologi yang muncul sebanyak 198 kesalahan. Kesalahan konjugasi kata kerja sebanyak 146 kesalahan dengan frekuensi $73,72 \%$ dan kesalahan siswa dalam mendeklinasi sebanyak 52 kesalahan dengan frekuensi 26,28\%. Faktor penyebab munculnya kesalahan tersebut adalah faktor performansi dan kompetensi.
\end{abstract}

\section{Kata Kunci: Analisis Kesalahan, Morfologi, Karangan Sederhana}

\begin{abstract}
The aim of this study was to obtain data and information about the error done by students class XI SMAN 2 Makassar in the level of morphology. This type of research was qualitative descriptive. Data collection was done by writing test in German. The analytical method used was agih method. The study population was class XI SMAN 2 Makassar consisting of 10 classes. The sample was random sampling. The number of samples was 1 class, namely; XI IPA 2 consisting of 24 students. The result showed that the morphology errors that appeared much; 198 errors. Verb conjugation error was 146 errors with the frequency $73.72 \%$ and a deklination error was 52 errors with a frequency $26.28 \%$. Factors which caused the error was a performance and competence.
\end{abstract}

Keywords: Error Analysis, M orphology, Simple Writing

\section{PENDAHULUAN}

Bahasa merupakan alat
komunikasi yang digunakan untuk
berinteraksi dalam kehidupan sehari-
hari. Di era modern saat ini, tuntutan
untuk mempelajari bahasa asing sangat
penting seiring dengan kemajuan

teknologi, informasi dan komunikasi yang semakin pesat. Karenanya, berkomunikasi tidak lagi terbatas pada bahasa ibu saja, tetapi juga bahasa asing yang saat ini sudah menjadi sebuah tuntutan dalam menghadapi era pasar global dan menghadapi 
Masyarakat Ekonomi Association of Southeast Asian Nations (ASEAN) .

Mempelajari bahasa asing saat ini merupakan kebutuhan yang harus dimiliki seseorang. Dengan penguasaan bahasa asing diharapkan seseorang dapat meningkatkan kompetensi berbahasa yang dimilikinya. Mengingat saat ini Indonesia telah banyak membangun kerja sama dengan negaranegara maju dan berkembang lainnya di dunia termasuk Jerman.

Keterampilan menulis sebagai salah satu dari empat keterampilan berbahasa mempunyai peranan penting. Menulis membuat seseorang dapat mengungkapkan pikiran, perasaan kepada orang lain. Akan tetapi, keterampilan menulis bahasa Jerman membutuhkan pemahaman pengetahuan tentang kaidah-kaidah bahasa Jerman, latihan yang tekun, serta motivasi belajar menulis bahasa Jerman.

Berdasarkan pengamatan yang dilakukan di SMAN 2 Makassar melalui informasi dari guru bidang studi bahasa Jerman, dari keempat kompetensi berbahasa yang telah diuraikan di atas, keterampilan menulis (Schreibfertigkeit) merupakan salah satu keterampilan yang paling sulit dikuasai oleh siswa. Kemampuan siswa dalam menulis bahasa Jerman pada umumnya masih tergolong rendah. Hal tersebut disebabkan karena perbedaan kaidah bahasa Jerman dengan bahasa Indonesia sebagai bahasa ibu serta motivasi belajar siswa yang masih kurang untuk menulis bahasa Jerman..

Kesalahan yang biasanya terjadi dalam menulis karangan bahasa Jerman adalah kesalahan morfologi. Morfologi merupakan salah satu cabang linguistik yang mempelajari tentang kata dan pembentukannya. Objek kajian dari morfologi adalah morfem. Morfem merupakan objek terkecil dari bahasa yang memiliki makna. Kesalahan morfologi yang kerap ditemui adalah kesalahan konjugasi dan kesalahan deklinasi. Kurangnya pemahaman siswa dalam kaidah bahasa Jerman dan kata benda dalam bahasa Jerman yang menggunakan artikel sangat bervariasi menjadi penyebab siswa biasanya melakukan kesalahan morfologi.

\section{ANALISIS KESALAHAN}

(KBBI) mendefenisikan analisis sebagai penyelidikan terhadap suatu peristiwa (karangan, perbuatan, dan sebagainya). Secara etimologi, analisis berasal dari bahasa Inggris analysis yang berarti pemisahan atau pemeriksaan yang diteliti, sedangkan dalam pengertian umum arti analisis adalah cara memeriksa suatu masalah, untuk menemukan semua unsur dasar dan hubungan antar unsur yang bersangkutan.

Berdasarkan pendapat para ahli dapat disimpulkan bahwa analisis merupakan salah satu tahap dalam penyelidikan terhadap suatu peristiwa atau keadaan untuk mengetahui apa

64 Eralingua : Jurnal Pendidikan Bahasa Asing dan Sastra Volume 1 No.1 Maret 2017 
yang terjadi atau keadaan yang sebenarnya, sehingga pada akhirnya dapat ditemukan kejelasan dari inti permasalahan.

Kesalahan berbahasa dapat diminimalkan dengan peran guru saat proses mengajar bahasa dengan mengkaji secara mendalam segala seluk-beluk kesalahan berbahasa itu. Ellis (dalam Setyawati, 2010:12) menyatakan bahwa terdapat lima langkah kerja analisis bahasa, yaitu:

1. Mengumpulkan sampel kesalahan

2. Mengidentifikasi kesalahan

3. Menjelaskan kesalahan

4. Mengklasifikasikan kesalahan

5. Mengevaluasi kesalahan.

Dari beberapa pendapat dapat disimpulkan bahwa langkah-langkah dalam menganalisis kesalahan merupakan suatu kegiatan yang dilakukan secara sistematis yang dilaksanakan dengan pengumpulan kesalahan, identifikasi kesalahan, mengklasifikan kesalahan-kesalahan, menyatakan frekuensi kesalahan, serta memperbaiki kesalahan yang muncul.

Menurut Tarigan (1987:276) jenis-jenis kesalahan dapat diklasifikasikan berdasar sudut taksonomi kategori linguistik meliputi kesalahan Fonologi, Morfologi, Sintaksis, dan Leksikal, taksonomi siasat permukaan, taksonomi komparatif, dan taksnomi efek komparatif.

Beberapa sumber dan penyebab kesalahan, antara lain:

\section{Pendapat Populer}

Pateda (1989:67) mengatakan bahwa pendapat populer menyebutkan kesalahan bersumber pada ketidakhatihatian siswa dan yang lain karena pengetahuan mereka terhadap bahasa yang dipelajari, dan interferensi.

2. Bahasa Ibu

Bahasa ibu mempengaruhi proses belajar bahasa kedua. Hal ini karena siswa sudah terbiasa dengan kaidah bahasa pertama. Dikatakan Ellis (dalam Pringgawidagda, 2002:169) bahwa pola-pola bahasa pertama dan bahasa kedua yang sama mendukung proses belajar, sedangkan pola-pola yang berbeda mendatangkan kesulitan.

3. Lingkungan

Pateda (1989:70) menjelaskan bahwa faktor lingkungan besar pengaruhnya terhadap kesalahan penggunaan bahasa siswa." Lingkungan yang turut mempengaruhi penguasaan bahasa siswa, meliputi lingkungan sekolah, rumah, dan lingkungan di masyarakat

4. Kebiasaan

Menurut Pateda (1989:71), kebiasaan berkaitan dengan pengaruh bahasa ibu dan lingkungan. Siswa terbiasa dengan pola-pola bahasa yang didengarnya.

5. Interlingual

Selingker (dalam Tarigan, 1988:300) menyebutkan bahwa interlingual adalah aktivitas belajar yang menghasilkan pola-pola pada bahasa kedua yang dipengaruhi oleh bahasa pertama. 
6. Interferensi

Baradja (dalam Hamid, 2005:17) menjelaskan bahwa interferensi adalah tuturan seseorang yang menyimpang dari norma-norma bahasa kedua, sebagai akibat dari kuatnya daya tarik pola yang terdapat pada bahasa kedua.

Berdasarkan pendapat para ahli di atas dapat disimpulkan bahwa faktor penyebab terjadinya kesalahan berbahasa siswa disebabkan oleh faktor interferensi yang merupakan pengaruh bahasa B1 terhadap bahasa yang sedang dipelajari siswa saat ini yakni bahasa Jerman. Selain itu faktor lingkungan dan kebiasaan juga menjadi penyebab kesalahan siswa dalam berbahasa Jerman.

\section{METODE PENELITIAN}

Variabel dalam penelitian in
adalah variabel tunggal yang mengamati kesalahan morfologi pada karangan sederhana siswa. Desain penelitian ini adalah penelitian deskriptif kualitatif, tujuannya untuk mendeskripsikan kesalahan morfologi karangan sederhana bahasa Jerman yang dilakukan oleh siswa, yaitu mendeskripsikan jenis-jenis kesalahan dalam mempelajari morfologi bahasa Jerman, frekuensi kesalahan yang dilakukan dan perkiraan faktor penyebab terjadinya kesalahan.

Variabel dalam penelitian ini adalah variabel tunggal. Penelitian ini bertujuan untuk mengetahui atau mendeskripsikan bentuk kesalahan morfologi pada karangan sederhana siswa kelas XI SMAN 2 Makassar. Kesalahan morfologi yang diteliti meliputi kesalahan konjugasi kata kerja yang terdiri atas konjugasi kata kerja beraturan (regelmaßige verben), kata kerja tidak beraturan (unregelmaßige verben), kata kerja yang dapat dipisah (trenbare verben), kata kerja yang tidak dapat dipisah (untrenbare verben), dan kata kerja bantu (Modalverben). dan kesalahan deklinasi yang terdiri atas kesalahan deklinasi artikel, kesalahan deklinasi kata ganti orang (personalpronomen), kesalahan deklinasi kata ganti milik (possesivepronomen).

Populasi dalam penelitian ini adalah keseluruhan siswa kelas XI SMAN 2 Makassar tahun ajaran 2016/2017 yang berjumlah 320 yang terbagi ke dalam 10 kelas. Sampel yang digunakan dalam penelitian ini adalah random sampling (sampel acak). Mengingat jumlah populasi yang sangat besar. Dari sepuluh kelas, terpilih kelas XI IPA 2 sebagai sampel pada penelitian ini.

Untuk mendapatkan data digunakan metode simak. Cara yang digunakan untuk memperoleh data dilakukan dengan menyimak penggunaan bahasa. Istilah menyimak tidak hanya berkaitan dengan penggunaan bahasa secara lisan tetapi juga penggunaan bahasa secara tertulis. Metode simak mempunyai teknik dasar yang berwujud teknik sadap. Teknik sadap disebut sebagai teknik dasar 
dalam metode simak karena pada hakikatnya penyimakan diwujudkan dengan penyadapan.

Dalam praktik selanjutnya teknik sadap diikuti dengan teknik lanjutan yang salah satunya berupa teknik catat. Teknik catat biasanya digunakan pada penggunaan bahasa secara tertulis sebagai lanjutan dari metode simak yang dikumpulkan diperoleh dengan menggunakan teknik catat. Dalam penelitian ini, peneliti mencatat kesalahan-kesalahan morfologi dalam karangan sederhana yang diteliti.

Instrumen dalam penelitian ini adalah tes kemampuan menulis berupa karangan sederhana dengan tema die Familie, yaitu tema yang sedang diajarkan di kelas XI. Penelitian ini menggunakan metode agih. Metode agih merupakan metode analisis yang alat penentunya merupakan bagian dari bahasa yang bersangkutan. Alat penentu kesalahan pada analisis ini adalah kaidah bahasa Jerman yang benar.

\section{Langkah-langkah yang} dilakukan sebagai berikut:

1. Membaca dengan cermat hasil karangan bahasa Jerman dari siswa.

2. Memberi tanda pada kesalalahankesalahan morfologi yang telah dikerjakan oleh siswa..

3. Mengelompokkan kesalahankesalahan yang dilakukan oleh siswa sesuai jenis-jenis kesalahan.

4. Mengelompokkan hasil analisis kesalahan ke dalam tabel analisis.
5. Menghitung frekuensi kemunculan kesalahan-kesalahan yang telah dikoreksi.

6. Mengkonsultasikan hasil analisis kepada seorang ahli atau expert judgement untuk memperoleh kebenaran data.

7. Menjelaskan penyebab terjadinya kesalahan yang dilakukan siswa.

Untuk mengetahuI frekuensi kesalahan digunakan rumus, sebagai berikut:

$$
\mathrm{X}=\frac{f^{\prime} n}{\sum f} \times 100
$$

Keterangan:

$\mathrm{X}=$ Frekuensi Kesalahan

$F$ n = Jumlah Kesalahan

$\Sigma=$ Jumlah Kesalahan Keseluruhan

Sudjana (dalam Arfan Mahri:2004)

\section{PEMBAHASAN}

Berikut adalah klasifikasi dan frekuensi dari kessalahan yang dilakukan oleh siswa, diantaranya sebagai berikut:

Tabel. 1 Klasifikasi dan Frekuensi

Kesalahan Morfologi Karangan siswa

\begin{tabular}{cccc}
\hline No. & $\begin{array}{c}\text { Kesalahan } \\
\text { Morfologi }\end{array}$ & Jumlah & Persentasi \\
\hline $\mathbf{1}$ & $\begin{array}{c}\text { Kesalaan } \\
\text { Konjugasi Kata } \\
\text { Kerja }\end{array}$ & 146 & $73,72 \%$ \\
\hline $\mathbf{2}$ & $\begin{array}{l}\text { Kesalahan } \\
\text { Deklinasi }\end{array}$ & 52 & $26,28 \%$ \\
& Total & 198 & $100 \%$ \\
\hline
\end{tabular}


Berdasarkan tabel di atas dapat diketahui bahwa jumlah kesalahan yang dilakukan oleh siswa sebanyak 198 kesalahan. Kesalahan-kesalahan tersebut terdiri dari kesalahan konjugasi kata kerja dan kesalahan deklinasi. Dari kedua klasifikasi kesalahan tersebut, kesalahan konjugasi kata kerja mempunyai frekuensi tertinggi yaitu 146 kesalahan dengan persentasi $73,72 \%$ dari keseluruhan kesalahan morfologi yang dibuat siswa. Selanjutnya terdapat kesalahan deklinasi sebanyak 52 kesalahan atau 26,28\% dari keseluruhan kesalahan mrfologi yang dibuat siswa.

Tabel. 2 Klasifikasi dan Frekuensi Kesalahan Konjugasi Kata Kerja Karangan siswa

\begin{tabular}{|c|c|c|c|}
\hline No. & $\begin{array}{c}\text { Kesalahan } \\
\text { Konjugasi Kata } \\
\text { Kerja }\end{array}$ & Jumlah & Persentasi \\
\hline 1 & $\begin{array}{c}\text { Kata kerja } \\
\text { beraturan } \\
\text { (regelmäßige } \\
\text { Verben) }\end{array}$ & 94 & $64,38, \%$ \\
\hline 2 & $\begin{array}{c}\text { Kata kerja tidak } \\
\text { beraturan } \\
\text { (unregelmäßige } \\
\text { Verben) }\end{array}$ & 39 & $26,71 \%$ \\
\hline 3 & $\begin{array}{c}\text { Kata kerja yang } \\
\text { dapat dipisah } \\
\text { (trennbare Verben) }\end{array}$ & 3 & $2,07 \%$ \\
\hline 4 & $\begin{array}{c}\text { Kata kerja yang } \\
\text { tidak dapat dipisah } \\
\text { (untrennbare } \\
\text { Verben) }\end{array}$ & 0 & $0 \%$ \\
\hline 5 & $\begin{array}{c}\text { Kata kerja modal } \\
\text { (Modalverben) }\end{array}$ & 10 & $6,84 \%$ \\
\hline & Total & 146 & $100 \%$ \\
\hline
\end{tabular}

Dari tabel di atas menunjukkan bahwa frekuensi kesalahan konjugasi kata kerja dalam karangan sederhana bahasa Jerman siswa berjumlah 146 kesalahan. Kesalahan konjugasi kata kerja beraturan (regelmaßige Verben) merupakan kesalahan yang paling banyak muncul dalam karangan siswa dengan jumlah 94 (64,38\%) kesalahan. Konjugasi kata kerja tidak beraturan (unregelmaßige Verben) dengan 39 $(26,71 \%)$ kesalahan, konjugasi kata kerja bantu (Modalverben) sebanyak 10 $(6,84 \%)$ kesalahan, konjugasi kata kerja dapat dipisah (trenbare Verben) sebanyak 3 (2,05\% kesalahan), dan tidak ditemui kesalahan konjugasi kata kerja yang tidak dapat dipisah (unttrenbare Verben).

Tabel. 3 Klasifikasi dan Frekuensi Kesalahan Deklinasi Karangan siswa

\begin{tabular}{clcc}
\hline No. & $\begin{array}{c}\text { Kesalahan } \\
\text { deklinasi }\end{array}$ & Jumlah & Persentasi \\
\hline $\mathbf{1}$ & $\begin{array}{l}\text { Deklinasi } \\
\text { artikel }\end{array}$ & 3 & $5,78 \%$ \\
\hline $\mathbf{2}$ & $\begin{array}{l}\text { Deklinasi kata } \\
\text { ganti orang }\end{array}$ & 1 & $1,92 \%$ \\
\hline $\mathbf{3}$ & $\begin{array}{l}\text { Deklinasi kata } \\
\text { ganti milik }\end{array}$ & 48 & $92,30 \%$ \\
\hline & Total & 52 & $100 \%$ \\
\hline
\end{tabular}

Dari tabel di atas menunjukkan bahwa frekuensi kesalahan konjugasi kata kerja dalam karangan sederhana bahasa Jerman siswa berjumlah 52 kesalahan. Kesalahan deklinasi yang sering muncul dalam karangan siswa dengan jumlah 48 (92,30\%) kesalahan. Selanjutnya kesalahan deklinasi artikel sebanyak $3(5,78 \%)$ kesalahan, dan 
hanya ditemukan 1 (1,92\%) kesalahan deklinasi kata ganti orang.

Kesalahan pengkonjugasian pada siswa disebabkan karena siswa keliru dalam mengkonjugasikan kata mogen 'suka' khususnya untuk orang pertama tunggal dan orang ketiga tunggal. Subjek ich dan er/sie/es memiliki konjugasi yang sama ketika membuat kalimat dengan menggunakan kalimat modal verben sehingga dapat dituliskan bahwa konjugasi yang tepat pada kata kerja tersebut adalah mag.

Berdasarkan paparan kesalahan konjugasi didapatkan 146 kesalahan siswa dalam mengkonjugasikan kata kerja dengan persentase 73,72\%. Dapat disimpulkan bahwa siswa masih belum memahami pengkonjugasian kata kerja, baik kata kerja beraturan maupun kata kerja tidak beraturan. Dalam pengkonjugasian kata kerja, siswa juga tidak memperhatikan subjek yang digunakan dalam kalimat tersebut sehingga menimbulkan kesalahan. Hal ini disebabkan karena faktor kompetensi, seperti yang dikatakan bahwa kesalahan kompetensi diakibatkan oleh kurangnya pengetahuan mengenai kaidah-kaidah bahasa Jerman. Kesalahan kompetensi merupakan penyimpanganpenyimpangan yang sistematis dan disebabkan oleh pengetahuan siswa yang sedang berkembang mengenai sistem bahasa kedua, yang disebut error. Jadi, ketika terjadi suatu kesalahan dalam suatu tulisan, siswa tidak dengan segera dapat memperbaiki bentuk - bentuk bahasa yang tidak benar.

Kesalahan selanjutnya yakni kesalahan deklinasi. Deklinasi merupakan perubahan bentuk pada nomina, pronomina atau adjektiva. Deklinasi tersebut berubah bentuk berdasarkan kasus yang mengikutinya, yaitu Kasus Nominativ, Genitiv, Dativ, dan Akkusativ berdasarkan Numerus, yaitu Singular atau Plural, dan berdasarkan Genus yaitu maskulin, feminim dan neutral. Banyaknya artikel kata benda yang ada dalam bahasa Jerman membuat siswa masih kurang bisa untuk menghafal seluruh artikel yang ada sehingga menimbulkan kesalahan dalam mendeklinasikan suatu kata. Dalam kaidah bahasa Jerman kata benda memiliki 3 Genus atau artikel yaitu der untuk benda maskulin, die untuk benda feminim, dan das untuk benda neutral untuk jenis artikel tentu (bestimmte Artikel), sedangkan untuk jenis artikel tak tentu (unbestimmte Artikel) adalah artikel ein (maskulin), eine (feminim) dan ein (neutral). Artikel-artikel ini dapat dideklinasikan dan berubah bentuk. Hal itu bisa dilihat pada kata kerja atau preposisi dalam kalimat. Namun, siswa kurang memperhatikan kaidah yang telah diungkapkan di atas, sehingga dalam karangan siswa muncul berbagai bentuk kesalahan dalam mendeklinasikan. Dalam penelitian ini membahas deklinasi kata ganti milik, 
deklinasi artikel, dan, deklinasi kata ganti orang.

Berdasarkan hasil penelitian ditemukan kesalahan deklinasi siswa sebanyak 52 dengan persentase 26,28\%. Kesalahan-kesalahan ini bersumber dari faktor intralingual, dimana siswa masih sulit atau kurang memahami landasan dalam merubah suatu kata dalam mendeklinasikan yang tepat sesuai kasus dan bentuknya yang sesuai dengan kaidah-kaidah dalam bahasa Jerman. Ketika siswa mendeklinasikan sebuah kata, maka banyak aspek yang perlu diperhatikan, seperti artikel pada kata benda atau kasus dalam kalimat tersebut, namun siswa kurang memperhatikan aspekaspek tersebut sehingga muncul berbagai jenis kesalahan dalam mendeklinasikan suatu kata. Selain itu, siswa juga masih belum banyak mengetahui artikel dari suatu kata benda, sehingga banyak terjadi kesalahan dalam mendeklinasikan kata benda.

\section{KESIMPULAN}

Berdasarkan pembahasan sebelumnya dapat disimpulkan bahwa kesalahan morfologi pada karangan bahasa Jerman siswa kelas XI IPA 2 SMAN 2 Makassar, terdiri dari kesalahan konjugasi dan kesalahan deklinasi. Jumlah kesalahan keseluruhan yang dilakukan oleh siswa adalah 198 kesalahan dengan frekuensi kesalahan konjugasi kata kerja 149 kesalahan atau $73,72 \%$ dari seluruh kesalahan morfologi yang dibuat siswa dan kesalahan deklinasi 52 kesalahan atau 26,28\% dari keseluruhan kesalahan mrfologi yang dibuat siswa.

Munculnya kesalahan konjugasi dan deklinasi yang terdapat pada karangan siswa bersumber dari interferensi bahasa pertama yakni bahasa Indonesia ke dalam bahasa Jerman sebagai bahasa kedua. Hal ini disebabkan oleh faktor performansi dan faktor kompetensi. Faktor performansi adalah faktor yang disebabkan karena performa siswa dalam mengarang. Performa yang dimaksud adalah kondisi emosional siswa dalam mengarang. Sedangkan faktor kempetensi adalah ketidaktahuan siswa tentang kaidah-kaidah atau aturan dalam bahasa Jerman.

\section{DAFTAR PUSTAKA}

Arikunto, Suharsimi. 2007. DasarDasar Evaluasi Pendidikan. Jakarta: Bumi Aksara.

Chaedar, Alwasilah. 1985. Linguistik Suatu Pengantar. Bandung: Angkasa.

Fleer, Sarah. 2008. Langenscheidt Kurzgrammatik Deutsch. Berlin- München: Langenscheidt KG.

Gie, The Liang. 2002. Terampil Mengarang. $\quad$ Yogyakarta: ANDI.

Hamid, Abdul. 2005. "Analisis Kesalahan Pelafalan Bahasa Jerman". Dalam Skripsi S1. Yogyakarta: FBS UNY.

Hastuti, Sri. 2003. Sekitar Analisis Kesalahan Berbahasa 
Indonesia. Yogyakarta: Mitra Gama Widya.

Helbig, G und J. Buscha. 2001. Deutsche Grammatik. Ein Handbuch für den Ausländerunterricht. Berlin und München: Langenscheidt.

Hufeisen dan Neuer. 2003. Mehrsprachigkeitskonzept-

Tertiärsprachenlernen-Deutsch nach English. Strasbourg: Council of Europe Publishing http://www.coe.int

Kleppin, Karin. 1997.Fehler und Fehlerkorrektur. München: Goethe-Institut.

Mahri, Arfan. 2004. Analisis Kesalahan Pelafalan Bunyi Vocal Bahasa Jerman Siswa Kelas III Bahasa SMU Negeri 3 Ujung Pandang. Skripsi FBS UNM.

Muslich, Masnur. 2009. Melaksanakan PTK Itu Mudah. Jakarta: Bumi Aksara.

Nababan, Sri Utari Subyakto. 1993. Metodologi Pengajaran Bahasa. Jakarta: Gramedia Pustaka Utama.

Pateda, Mansoer. 1989. Analisis Kesalahan. NTT: Nusa Indah.
Pelz, Heidrun. 1984. Linguistik für Anfänger. Hamburg: Hoffmann und Campe Verlag.

Pringgawidagda, S. 2002. Strategi Penguasaan Berbahasa. Yogyakarta: Adicita Karya Nusa.

Resmini. 2009. Kebahasaan. Bandung UPI Press

Setyawati, Nanik. 2010. Analisis Kesalahan Berbahasa Indonesia. Teori dan Praktik. Surakarta. Yuma Pustaka.

Soeparno. 2002. Dasar- Dasar Linguistik Umum. Yogyakarta: Tiara Wacana.

Suparno, Yunus. 2011. Keterampilan Dasar Menulis. Jakarta. Universitas Terbuka

Sudaryanto. 1993. Metode dan Aneka Teknik Analisis Bahasa. Yogyakarta: Duta Wacana University Press.

Tarigan, Henry Guntur. 1988. Pengajaran Pemerolehan Bahasa. Jakarta: Tenaga Pendidikan Jakarta.

1997. Menyimak sebagai Suatu Keterampilan Berbahasa. Bandung: Angkasa 